\title{
Sociobiology
}

RESEARCH ARTICLE - ANTS

\section{Seasonal Analysis of Taxonomic and Functional Diversity of Poneromorph Ant Assemblages in the Amazon Forest}

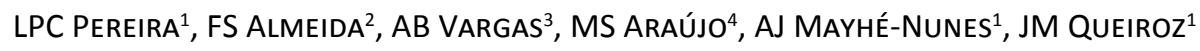 \\ 1 - Universidade Federal Rural do Rio de Janeiro, Seropédica-RJ, Brazil \\ 2 - Universidade Federal Rural do Rio de Janeiro, Três Rios-RJ, Brazil \\ 3 - Centro Universitário de Volta Redonda (UniFOA), Volta Redonda-RJ, Brazil \\ 4 - Universidade Estadual Paulista, São José do Rio Preto-SP, Brazil
}

\section{Article History}

\section{Edited by}

Gilberto M. M. Santos, UEFS, Brazil

Received 28 April 2016

Initial acceptance 26 May 2016

Final acceptance 02 August 2016

Publication date 25 October 2016

\section{Keywords}

Biodiversity, Formicidae, protected area.

\section{Corresponding author}

Jarbas Marçal de Queiroz

Depto. de Ciências Ambientais

Instituto de Florestas/UFRRJ

BR 465, Km 7, Seropédica-RJ, Brasil

E-Mail: jarquiz@gmail.com

\begin{abstract}
The present study aimed at assessing the effects of climate seasonality on poneromorph ants in the Brazilian Amazon, by studying variations in composition, richness, and taxonomic and functional diversity. The study was carried out in the Tapirapé-Aquiri National Forest, southeastern Pará State. We collected poneromorph ants in three areas of native forest with pitfall traps and sardine baits on the ground and vegetation, in two dry and rainy seasons. We collected 46 species of poneromorph ants, which belong to two subfamilies and eleven genera. The species composition, richness and taxonomic diversity did not vary significantly between seasons. There was no significant difference in the frequency of species of functional groups between dry and rainy seasons. There was no significant difference in the average richness and average diversity of functional groups between the dry and rainy seasons. In our study we found no seasonal differences in composition, taxonomic and functional richness and diversity of poneromorph ants in the Amazon, which is useful for future studies that aim at using those ants as bioindicators. In addition, the identification of the species made in the present study has special relevance as it contributes to advance the knowledge of poneromorph ant diversity in the Amazon.
\end{abstract}

\section{Introduction}

The interaction between environmental conditions (e.g., temperature and humidity) and resource availability influences ecological communities (Townsend et al., 2006). More studies are needed to understand how spatial and temporal variations in environmental factors affect communities of different types of organisms. Although tropical rainforests are not considered restrictive environments in terms of conditions and resources (Townsend et al., 2006), variations in geology, relief, or climate can influence communities (Peroni \& Hernandez, 2011).

A phenomenon is considered seasonal when it occurs in a predictable way at the same time every year (Wolda, 1988). Although climate seasonality is lower at low latitudes, the Brazilian Amazon has two climate types with marked seasonality (Souza Filhoet al., 2005; Alvares et al., 2013). Variations in rainfall throughout the year may influence organisms, but little is known about those effects, as most studies involve sampling restricted to a single season. This information might help understand how ecological communities respond to environmental changes (Leivas \& Carneiro, 2012; Schmitz et al., 2014).

In the Amazon, ants and termites represent threequarters of the biomass of the soil fauna (Fittkau \& Klinge, 1973) and play important ecological roles in the functioning of this ecosystem (Hölldobler \& Wilson, 1990; Fowler et al., 1991; Gotwald, 1995). Although poneromorph ants are not a monophyletic group, they are ecologically similar enough to be analyzed together (Jimenez et al., 2008). In spite of being frequently called hunting ants (Jimenez et al., 2008), 
poneromorph ants have a diversified diet, which includes live and dead prey, fruits, seeds, and liquids produced by plants or obtained from other insects (Medeiros, 1997; Lattke, 2003; Jimenez et al., 2008). Some species of poneromorph ants are important seed dispersers (Passos \& Oliveira, 2002, 2004; Almeida et al., 2013). They also have diversified nesting habits, including species that build nests in the soil, leaf litter, and trees (Lattke, 2003; Jimenez et al., 2008; Wilkie et al., 2010).

Previous studies carried out in the Amazon tested the effect of factors, such as the amount of leaf litter and competition, on the ant community (Bastos \& Harada, 2011; Baccaro et al., 2012), but the influence of climate is still poorly known. Seasonal variations in climate affect insects directly and indirectly (Wolda, 1988). Climate conditions affect ant foraging and their development speed (Hölldobler \& Wilson, 1990; Vogt et al., 2003; Almeida et al., 2007). Indirectly, climate factors affect resource availability to ants as they interfere with primary productivity (Silva et al., 2014). Low resource availability can lead to higher interspecific competition and species exclusion, and is one of the regulating factors of ant communities (Lach, 2005; Carpintero \& Reyes-López, 2008).

Few studies have assessed the effects of environmental factors on the functional diversity of ants (e.g. Groc et al., 2014) and most of them were carried out by sampling the community at a single season. Hence, the present study aimed at assessing the effects of climate seasonality on poneromorph ants in the Brazilian Amazon, by studying variations in composition, richness, and taxonomic and functional diversity.

\section{Material and Methods}

\section{Study area}

The present study was carried out in the TapirapéAquiri National Forest, which has an area of 196,351.42 ha and is located within the municipalities of Marabá and São Félix do Xingú, southeastern of Pará State. The climate is classified as tropical rainy type Awi in the Köppen system, with monthly temperatures above $18^{\circ} \mathrm{C}$, annual rainfall from 2,000 to $2,400 \mathrm{~mm}$, and a dry season in winter (Rolim et al., 2006). The rainy season occurs from December to April and the dry season from June to October (MMA, 2006). The average monthly temperature in Marabá and São Félix do Xingú from 1973 and 1990 varied from 24.3 to $26.9^{\circ} \mathrm{C}$ and from 24.6 to $25.4{ }^{\circ} \mathrm{C}$, respectively (EMBRAPA, 2015). The average monthly rainfall varied from 21 (driest month) to 387 mm (rainiest month) in Marabá and from 17 to $322 \mathrm{~mm}$ in São Félix do Xingú (EMBRAPA, 2015).

\section{Sampling}

We collected poneromorph ants in three areas of native forest (A1, A2, and A3) in the dry seasons of 2009 (dry season I) and 2010 (dry season II), and the rainy seasons of 2010 (rainy season I) and 2011 (rainy season II). In the areas A1 (05 $\left.49^{\prime} \mathrm{S}, 50^{\circ} 30^{\prime} \mathrm{W}\right)$ and A2 (05 $\left.49^{\circ} \mathrm{S}, 50^{\circ} 29^{\prime} \mathrm{W}\right)$ we determined four sampling sites inside the forest, at distances of $0,100,500$, and $1,000 \mathrm{~m}$ from the edge. In the area A3 $\left(05^{\circ} 46^{\prime} \mathrm{S}\right.$, $50^{\circ} 31^{\prime} \mathrm{W}$ ), we determined only one sampling site inside the forest at $500 \mathrm{~m}$ from the edge. At each distance we marked a 10 x $90 \mathrm{~m}$ plot to arrange the traps. During the sampling session of January 2011 (rainy season II), it was not possible to sample the area $\mathrm{A} 1$, due to access problems caused by the seasonal rains; therefore, the sampling effort was lower in that season.

In each sampling site, we distributed pairs of sardine baits on pieces of white paper on the ground and on the vegetation at approximately $1 \mathrm{~m}$ above the ground. The pairs of baits were arranged on the edges of the plots, $10 \mathrm{~m}$ away from one another, in a total of 20 baits on the ground and 20 baits on the vegetation per plot. The baits remained in the field for $1 \mathrm{~h}$ and after that each paper containing baits was individually transferred to plastic bags for sorting of the material in the laboratory. In the same plots, after sampling with baits, we installed pitfall traps, at every $10 \mathrm{~m}$, which were made of 300-ml plastic cups containing $100 \mathrm{ml}$ of alcohol $80 \%$, in a total of 20 traps per plot. Fortyeight hours later we removed the traps, placed their contents in plastic recipients, and took them to the laboratory for sorting and replacing of the fixing liquid with alcohol $70 \%$.

We identified ant genera following the key of Bolton (1994) and classified subfamilies following Bolton (2003). We also followed the classification proposed by Schmidt \& Shattuck (2014). We identified ants to the species following available dichotomic keys published in taxonomic revisions. In addition, we compared the collected ants with identified specimens deposited in the Costa Lima Entomological Collection (CECL) at the Institute of Biology of the Federal Rural University of Rio de Janeiro. All vouchers were deposited in the same collection.

We obtained from the literature information on diet and nesting sites of the species collected. We classified each species as omnivorous, predator, or detritivorous. We observed that poneromorph ants make nests in the underground (in the soil or under rocks), in the leaf litter (nesting on the soil in wood, branches, seeds, fruits or among leaves), or on the vegetation. However, it was not possible to determine the diet or nesting site of some species.

We classified the species in functional groups, based on the literature (Delabie et al., 2000; Silvestre et al., 2003; Silva \& Brandão, 2010; Macedo et al., 2011; Groc et al., 2014). Functional groups are species sets that show similar characteristics and influence on ecosystem processes (Diaz \& Cabido, 2001; Silva \& Brandão, 2010). We classified poneromorph ant species in the following functional groups, according to diet and nesting habit: omnivores inhabiting the soil, omnivores inhabiting the soil and plants, omnivores inhabiting plants, detritivores inhabiting the soil, generalist predators inhabiting the soil, generalist predators inhabiting the soil and plants, generalist predators inhabiting plants, specialist predators inhabiting the soil. For the species whose 
information on diet or nesting habits was not available, we used the information on the genus to allocate the ants into a functional group.

Data analysis

We built species accumulation curves using the MaoTau method with a confidence interval of $95 \%$ in the program EstimateSWin 8.0 (Colwell, 2006). We considered an overlap in the confidence intervals of two species accumulation curves as evidence that they do not differ from one another (Gomes et al., 2013).

We used the analysis of variance and the Tukey test to test for differences in taxonomic and functional richness and diversity between the dry and rainy seasons. Average values were calculated per plot, and we pooled all species collected with the three methods (baits on the soil, baits on the vegetation, and pitfalls). We used a chi-square test $\left(\chi^{2}\right)$ to compare relative richness and relative abundance (obtained by the frequency of species in samples) of the functional groups between the dry and rainy seasons.

We also used a non-metric multidimensional scaling (NMDS) and an ANOSIM to compare species composition of the poneromorph ants between the dry and rainy seasons, based on the Bray-Curtis distance. This analysis was carried out in the program PAST (Hammer et al., 2001).

\section{Results and Discussion}

We collected 46 species of poneromorph ants, which belong to two subfamilies and eleven genera (Table 1). Gnamptogenys was the genus with the highest species richness (nine species), followed by Odontomachus (seven species), Neoponera (six species), and Hypoponera (five species). Approximately 450 species of poneromorph ants are known for the Neotropics, which represent $13 \%$ of the ant fauna of the region (Bolton, 1995; Lattke, 2003; Fernández \& Sendoya, 2004). In tropical forests, some ant groups are highly diverse (Hölldobler\& Wilson, 1990; Vasconcelos et al., 2003) and the identification of their species is difficult due to taxonomic controversies (Lyal \& Weitzman, 2004). However, these controversies are minor for other groups, such as poneromorphs, which allow studies to identify most ants to the species, which makes them more detailed and precise. Such studies are useful in the definition of priorities for conservation, as they allow comparisons of species inventories between different localities, as the sampling effort and techniques used vary between studies (Bestelmeyer et al., 2000).

Ectatomma lugens Emery, 1894 was the species with the highest frequency of occurrence and was present in all seasons. Next, the species with high frequencies were Pachycondyla crassinoda (Latreille, 1802) and Gnamptogenys concinna (Fr. Smith, 1858), which were also present in all seasons. The species $E$. lugens has generalistic habits and broad distribution in tropical forests (Fernandez, 1991), which could explain its high frequency.
Among the species identified, $39 \%$ nest only in the leaf litter, $32 \%$ make underground nests or nest in the leaf litter, $11 \%$ have only underground nests, and $7 \%$ nest only on the vegetation. Two species can have subterraneous nests, nests in the leaf litter, or on the vegetation, whereas one species has already been observed nesting in the leaf litter or on the vegetation. It was not possible to obtain information on the nesting habits of two species. In terms of diet, $66 \%$ of the species identified are predators, $27 \%$ are omnivores, and only one species was classified as detritivore. The feeding habits of two species are unknown. As in other studies (e.g. Lattke, 2003; Fernández \& Arias-Penna, 2008; Jimenez et al., 2008), most poneromorph ants found use the soil or the leaf litter for nesting and are predators. In addition, Wilkie et al. (2010) also observed that a relatively small number of ant species use more than one vertical stratum of the forest. However, it is important to highlight that in the present study the sampling effort was lower on the vegetation than in the soil.

Thirteen ant species were collected in a single sample ( $28 \%$ of the total of species), four species in two samples $(9 \%$ of the total of species), and four species in three samples. The low frequency of occurrence observed in several ant species is common in inventories carried out in Brazil (Braga et al., 2010; Vargas, 2011).

Species accumulation curves indicated no significant difference in species richness between seasons (Fig 1 and Fig 2). The fact that many ant species are infrequent creates a need for using a larger sampling effort. However, in the present study, even with a large number of samples the species accumulation curve did not reach an asymptote. This is partially explained by the high diversity of the group (Silva \& Silvestre, 2000).

The average species richness did not vary significantly between seasons (Table 2, ANOVA, $\mathrm{F}=0.68, \mathrm{P}=0.57$ ) and the same occurred with species diversity (ANOVA, $\mathrm{F}=1.56$, $P=0.22)$. Twenty-seven ant species were collected in at least one dry and one rainy season (59\% of the total of species). Hence, there was no significant difference between ant communities collected in different seasons $(\mathrm{R}=0.035 ; \mathrm{P}=0.24)$.

The functional group with the highest species richness was generalist predators inhabiting the soil, followed by the group of omnivores inhabiting the soil (Table 3). However, the group of the omnivores inhabiting the soil was the most abundant, followed by the generalist predators inhabiting the soil. Species with a generalist diet, mainly omnivores, can reach higher abundance as they may use different kinds of food. There was no significant difference in the frequency of species of functional groups between dry and rainy seasons (Table 3, Chi-Squared Test, $\chi 2=7.15, \mathrm{GL}=21 ; \mathrm{P}=0.99$ ). The same occurred with the abundance of functional groups (Chi-Squared Test, $\chi 2=28.85, \mathrm{GL}=21, \mathrm{P}=0.12$ ). There was no significant difference in the average richness (Table 4, ANOVA, $\mathrm{F}=0.338, \mathrm{P}=0.80$ ) and average diversity of functional groups between the dry and rainy seasons (ANOVA, $\mathrm{F}=1.01, \mathrm{P}=0.37$ ). 
Table 1. Species list of poneromorph ants and their frequency of occurrence in the dry and rainy seasons. $\mathrm{T}=$ total frequency of occurrence of each species. Nesting: $\mathrm{Sub}=$ subterraneous nests, $\mathrm{Lit}=$ leaf litter nests, $\mathrm{Veg}=$ nests on live vegetation, $\mathrm{U}=$ unknown. Diet: $\mathrm{O}=$ omnivorous, $\mathrm{P}=$ predator, $\mathrm{D}=$ detritivorous, $\mathrm{U}=$ Unknown.

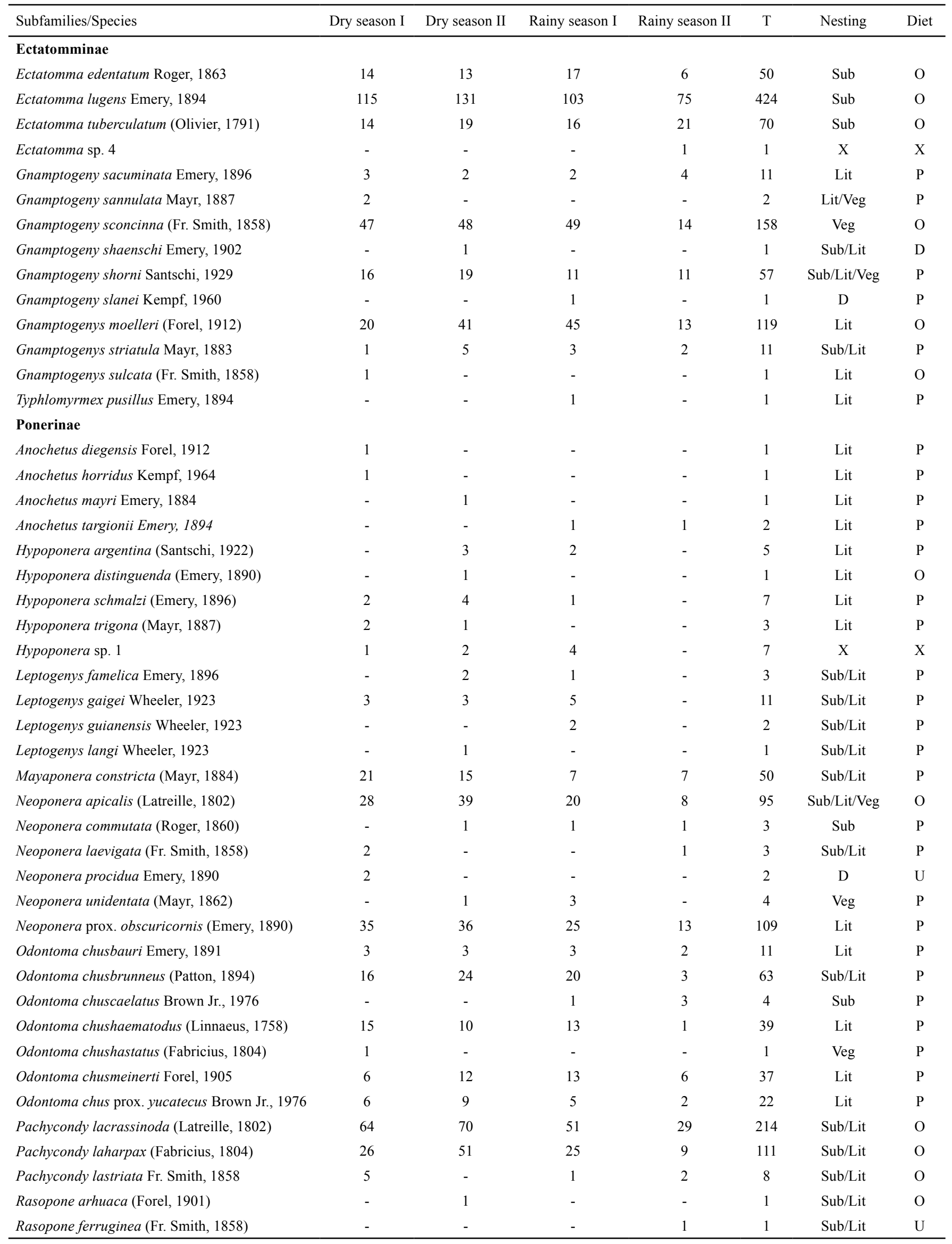



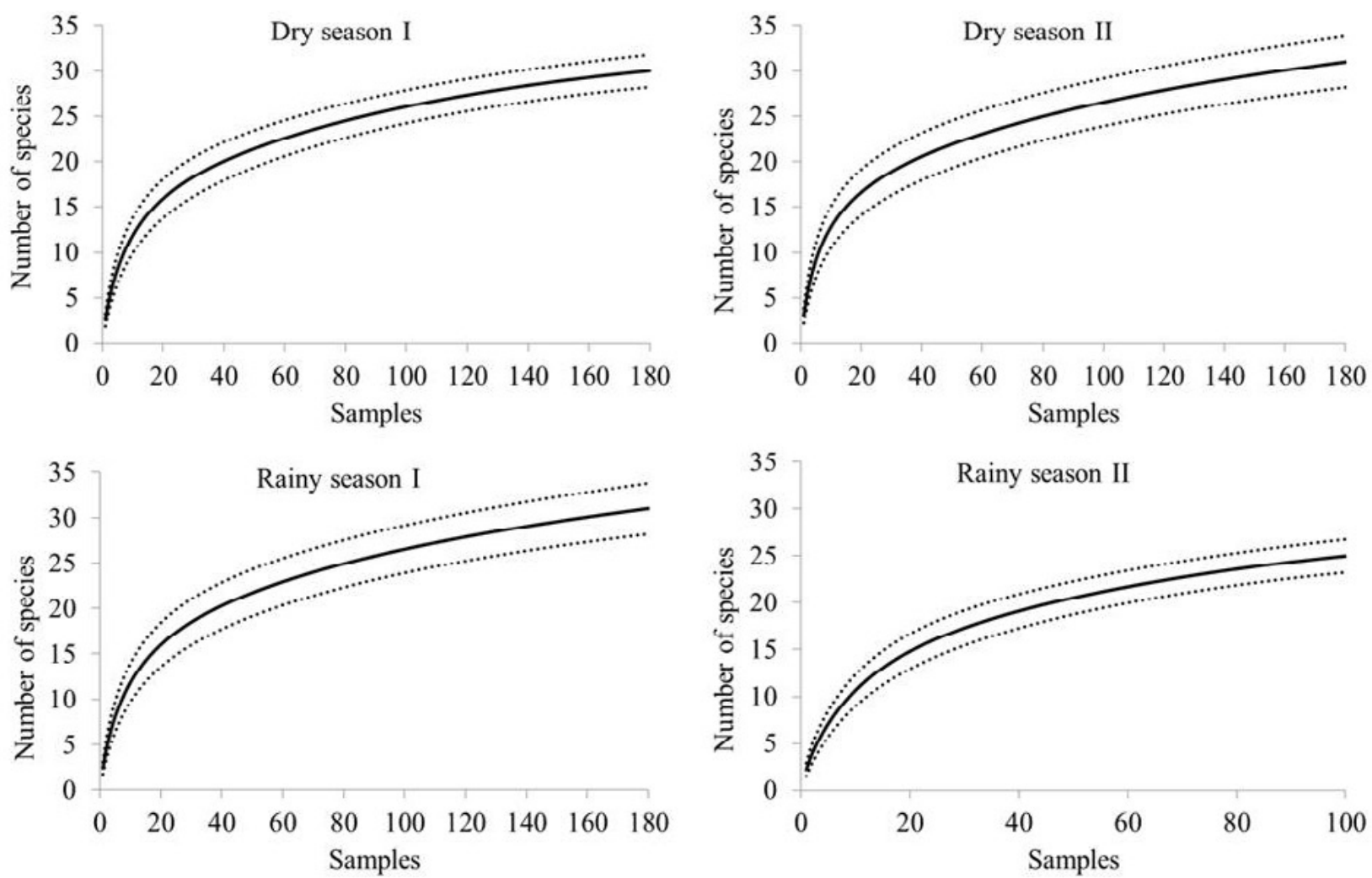

Fig 1.Species accumulation curves (Mao-Tau) and 95\% confidence interval for the fauna of poneromorph ants collected in the dry and rainy seasons.

The temperature and rainfall are among the environmental factors that influence the ants. In the study region, temperature does not vary much throughout the year (EMBRAPA, 2015). This fact can explain the lack of differences in species composition and taxonomic and functional diversity between seasons. Rainfall, though, varies largely throughout the year (EMBRAPA, 2015). However, even with such variation in rainfall, the fauna of poneromorph ants did not vary between the rainy and dry seasons. Other authors observed variation in species richness or diversity between the dry and rainy seasons in the Atlantic Forest (Coelho \& Ribeiro, 2006; Vargas et al., 2007), but the results can be

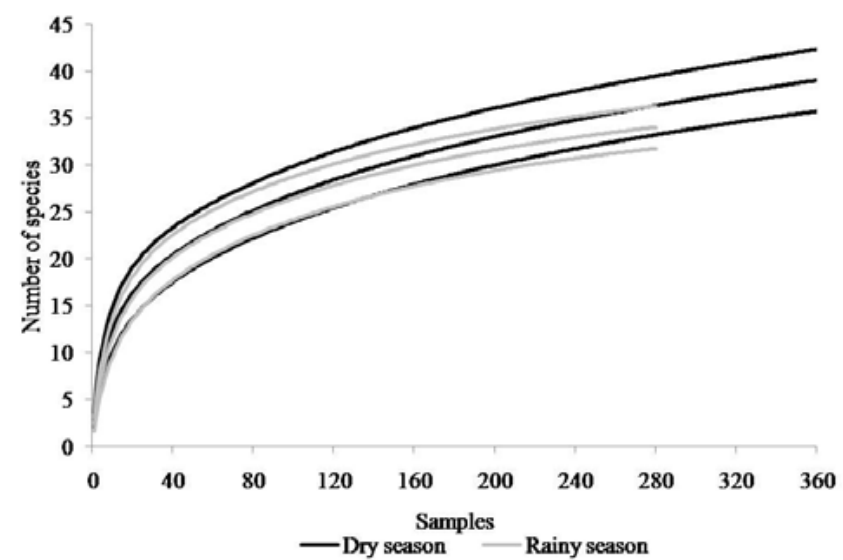

Fig 2. Species accumulation curves (Mao-Tau) and 95\% confidence interval for the fauna of poneromorph ants collected in the dry and rainy seasons. explained by higher average temperature in the rainy season. A seasonal increase in resource availability can be connected to an increase in taxonomic and functional diversity, as it allows ant populations to grow and, consequently, the number of foraging worker ants also grows (Silva et al., 2014). On the other hand, in other studies in the Atlantic Forest the effects of climate seasonality on ant species richness or diversity were not observed (Neves et al., 2010; Montine et al., 2014).

The lack of differences in community composition and functional groups can be related to the small number of specialist species. Populations of generalist species can probably remain stable throughout the year, as they have higher food availability.

Table 2. Species richness and Shannon diversity ofponeromorph ants collected in the dry and rainy seasons in the Tapirapé-Aquirí National Forest, Pará, Brazil.

\begin{tabular}{ccccc}
\hline Variable & $\begin{array}{c}\text { Dry season } \\
\text { I }\end{array}$ & $\begin{array}{c}\text { Dry season } \\
\text { II }\end{array}$ & $\begin{array}{c}\text { Rainy season } \\
\text { I }\end{array}$ & $\begin{array}{c}\text { Rainy season } \\
\text { II }\end{array}$ \\
\hline $\begin{array}{c}\text { Total } \\
\text { Richness }\end{array}$ & 30 & 31 & 31 & 25 \\
$\quad$ Total & 2.63 & 2.64 & 2.67 & 2.48 \\
$\begin{array}{c}\text { Diversity } \\
\text { Average }\end{array}$ & & & & \\
$\begin{array}{c}\text { Richness } \\
( \pm \text { SD) }\end{array}$ & $14.67 \pm 2.74$ & $15.56 \pm 1.67$ & $14.56 \pm 2.51$ & $13.80 \pm 1.92$ \\
$\begin{array}{c}\text { Average } \\
\text { Diversity } \\
( \pm \text { SD) }\end{array}$ & $2.29 \pm 0.17$ & $2.37 \pm 0.12$ & $2.31 \pm 0.22$ & $2.17 \pm 0.12$ \\
\hline
\end{tabular}


Table 3. Relative richness and abundance of functional groups of poneromorph ants collected in the dry and rainy seasons in the TapirapéAquirí National Forest, Pará, Brazil.

\begin{tabular}{|c|c|c|c|c|}
\hline \multirow{2}{*}{ Functional groups } & Dry season I & Dry season II & Rainy season I & Rainy season II \\
\hline & \multicolumn{4}{|c|}{ Relative richness (\%) } \\
\hline Omnivores inhabiting the soil & 27.6 & 25.8 & 22.6 & 36.0 \\
\hline Omnivores inhabiting plants & 3.4 & 3.2 & 3.2 & 4.0 \\
\hline Detritivores inhabiting thesoil & 0.0 & 3.2 & 0.0 & 0.0 \\
\hline Generalist predators inhabiting the soil and plants & 6.9 & 3.2 & 3.2 & 4.0 \\
\hline Specialist predators inhabiting the soil & 6.9 & 3.2 & 3.2 & 8.0 \\
\hline \multirow[t]{2}{*}{ Generalist predators inhabiting plants } & 3.4 & 3.2 & 3.2 & 0.0 \\
\hline & \multicolumn{4}{|c|}{ Relative abundance (\%) } \\
\hline Omnivores inhabiting the soil & 54.0 & 57.5 & 57.1 & 66.5 \\
\hline Generalist predators inhabiting the soil & 24.8 & 23.4 & 24.3 & 18.6 \\
\hline Generalist predators inhabiting the soil and plants & 3.9 & 3.3 & 2.4 & 4.7 \\
\hline Specialist predators inhabiting the soil & 0.9 & 0.2 & 0.2 & 0.8 \\
\hline Generalist predators inhabiting plants & 0.2 & 0.2 & 0.7 & 0.0 \\
\hline
\end{tabular}

The lack of response of the ant fauna to climate seasonality can also indicate that there are no expressive variations in resource availability throughout the year or that the variations in climate in the region are not strong enough to impact the fauna of poneromorph ants. In addition, taxonomic and functional variations in leaf litter ant communities in the Amazon can occur due to changes in environmental heterogeneity, which affects abiotic variables (Groc et al., 2014). Hence, these ant species can be more influenced by the microclimate, which is more homogeneous throughout the year within the forest, than by the regional climate.

Given the present results, it is important to keep on searching for other factors, such as microclimate, ecological interactions, and evolutionary history, which may help understand the most important structuring processes for poneromorph ants in the study region. It is important to highlight that the environmental heterogeneity is cited as an important regulator of the ant fauna (Vargas et al., 2007; Martins et al., 2011; Gomes et al., 2013). As most species sampled use the leaf litter for nesting or searching for food, new studies can assess the influence of the leaf litter amount and composition on poneromorph ants in the Amazon.

Ants are considered a bioindicator group (Silva \& Brandão, 1999). However, assessing the whole ant fauna can be difficult, as the species of some genera are hard to identify. This problem can be minimized by restricting the study to a taxonomically well-known group of ants, such as poneromorphs. In this way, more complete inventories can be compiled, and the results of the studies will be more precise and comparable between localities.
Table 4. Species richness and Shannon diversity of functional groups of poneromorph ants collected in the dry and rainy seasons in the Tapirapé-Aquirí National Forest, Pará, Brazil.

\begin{tabular}{ccccc}
\hline Variable & $\begin{array}{c}\text { Dry season } \\
\text { I }\end{array}$ & $\begin{array}{c}\text { Dry season } \\
\text { II }\end{array}$ & $\begin{array}{c}\text { Rainy season } \\
\text { I }\end{array}$ & $\begin{array}{c}\text { Rainy season } \\
\text { II }\end{array}$ \\
\hline $\begin{array}{c}\text { Total } \\
\text { Richness } \\
\text { Total }\end{array}$ & 7 & 8 & 7 & 6 \\
$\begin{array}{c}\text { Diversity } \\
\text { Average }\end{array}$ & 1.26 & 1.20 & 1.18 & 1.05 \\
$\begin{array}{c}\text { Richness } \\
( \pm \text { SD })\end{array}$ & $5.33 \pm 0.50$ & $5.22 \pm 0.67$ & $5.00 \pm 0.87$ & $5.20 \pm 0.84$ \\
$\begin{array}{c}\text { Average } \\
\text { Diversity } \\
( \pm \text { SD })\end{array}$ & $1.18 \pm 0.14$ & $1.15 \pm 0.14$ & $1.10 \pm 0.25$ & $1.01 \pm 0.16$ \\
\hline
\end{tabular}

In our study we found no seasonal differences in composition and in taxonomic and functional diversity of poneromorph ants in the Amazon, which is useful for future studies that aim at using those ants as bioindicators. In addition, the identification of the species made in the present study has special relevance as it contributes to advance the knowledge of poneromorph ant diversity in the Amazon.

\section{Acknowledgments}

To Faperj (Proc.101.472/2010) for a research fellowship to JMQ, and to Habtec for the logistic support. We also thank Rodrigo M. Feitosa and an anonymous referee for their helpful comments on an early version of the manuscript. 


\section{References}

Almeida, F.S., Queiroz, J.M. \& Mayhé-Nunes, A.J. (2007). Distribuição e abundância de ninhos de Solenopsis invicta Buren (Hymenoptera: Formicidae) em um agroecossistema diversificado sob manejo orgânico. Floresta e Ambiente, 14: $33-43$.

Almeida, F.S., Mayhé-Nunes, A.J. \& Queiroz, J.M. (2013). The importance of poneromorph ants for seed dispersal in altered environments. Sociobiology, 60: 229-235. doi: 10.13 102/sociobiology.v60i3.229-235

Alvares, C.A., Stape, J.L., Sentelhas, P.C., Gonçalves, J.L.M., Sparovek, G. (2013). Köppen's climate classification map for Brazil. Meteorologische Zeitschrift, 22: 711-728. doi: 10.1127/0941-2948/2013/0507

Baccaro, F.B., Souza, J.L.P., Franklin, E.,Landeiro, V.L. \& Magnusson, W.E. (2012). Limited effects of dominant ants on assemblage species richness in three Amazon forests. Ecological Entomology, 37: 1-12. doi: 10.1111/j.1365-2311. 2011.01326.x

Bastos, A.H.S. \& Harada, A.Y. (2011). Leaf-litter amount as a factor in the structure of a ponerineants community (Hymenoptera, Formicidae, Ponerinae) in an eastern Amazonian rainforest, Brazil. Revista Brasileira de Entomologia, 55: 589596. doi: 10.1590/S0085-56262011000400016

Bestelmeyer, B.T., Agosti, D., Alonso, L.E., Brandão, R.F., Brown JR., W.L., Delabie, J.H.C. \& Silvestre, R. (2000). Field techniques for the study of ground-dwelling ants: an overview description and evaluation. In: D. Agosti, J.D. Majer, L.E. Alonso \& T.R. Schultz (Eds). Ants: standard methods for measuring and monitoring biodiversity (pp. 122144). Washington: Smithsonian Institution Press.

Bolton, B. (1994). Identification guide to the ant genera of the world. Massachusetts: Havard University Press, 222p.

Bolton, B. (1995). A taxonomic and zoogeographical census of the extant ant taxa (Hymenoptera: Formicidae). Journal of Natural History, 29: 1037-1056. doi: 10.1080/ 00222939500770411

Bolton, B. (2003). Synopsis and classification of Formicidae. Memoirs of the American Entomological Institute, 71: 1-370.

Braga, D.L., Louzada, J.N.C., Zanetti, R. \&Delabie, J. (2010). Avaliação rápida da diversidade de formigas em sistemas de uso do solo no sul da Bahia. Neotropical Entomology, 39: 464-468. doi: 10.1590/S1519-566X2010000400002

Carpintero, S. \& Reyes-López, J. (2008). The role of competitive dominance in the invasive ability of the Argentine ant (Linepithemahumile). Biological Invasions, 10: 25-35. doi: 10.1007/s10530-007-9103-3

Coelho, I.R. \& Ribeiro, S.P. (2006). Environment heterogeneity and seasonal effects in ground-dwelling ant
(Hymenoptera: Formicidae) assemblages in the Parque Estadual do Rio Doce, MG, Brazil. Neotropical Entomology, 35(1): 19-29. doi: 10. 1590/S1519-566X2006000100004

Colwell, R.K. (2006). EstimateS: Statistical estimation of species richness and shared species from samples. Version 8.0. <viceroy.eeb.uconn.edu/estimates $>$. Accessed date: December 12th. 2011.

Diaz, S. \& Cabido, M. (2001). Vive la difference: plant functional diversity matters to ecosystem processes. Trends in Ecology and Evolution, 16: 646-655. doi:10.1016/S01695347(01)02283-2

Delabie, J.H.C., Agosti, D. \& Nascimento, I.C. (2000). Litter ant communities of the Brazilian Atlantic rain forest region. In: D. Agosti, J. Majer, L. Alonso, T.Schultz (Eds), Sampling grounddwelling ants: case studies from the world's rain forests (pp. 1-17). Perth: School of Environmental Biology (Bulletin 18).

EMBRAPA - Empresa Brasileira de Pesquisa Agropecuária. (2015). Banco de dados climáticos do Brasil. <http://www. bdclima.cnpm.embrapa.br/resultados/index.php?UF $=$ pa $>$. Accessed date: August 11th. 2015.

Fernandez, F. (1991). Las hormigas cazadoras del género Ectatomma (Formicidae: Ponerinae) en Colombia. Caldasia, 16: 551-564.

Fernández, F. \& Arias-Penna, T.M. (2008). Las hormigas cazadoras en la región Neotropical. In. E. Jiménez, F. Fernández, T.M. Arias \& F.H. Lozano-Zambrano (Eds.), Sistemática, biogeografía y conservación de las hormigas cazadoras de Colombia (pp.3-39). Bogotá: Instituto de Investigaciónde Recursos Biológicos Alexander von Humboldt.

Fernández, F. \&Sendoya, S. (2004). List of Neotropical Ants. Biota Colombiana, 5: 3-88.

Fittkau, E.J. \& Klinge, H. (1973).On biomass and trophic structure of the Central Amazonian rain forest ecosystem. Biotropica, 5: 2-14. doi: 10.2307/2989676

Fowler, H.G.L., Forti, C.; Brandão, C.R.F.; Delabie J.H.C. \& Vasconcelos, H.L. (1991). Ecologia nutricional de formigas. In A.R. Pazzini, \& J.R.P. Parra (Eds), Ecologia nutricional de insetos e suas implicações no manejo de pragas (pp. 131-209). São Paulo: Manole.

Gomes, D.S., Almeida, F.S., Vargas, A.B. \& Queiroz, J.M. (2013). Resposta da assembleia de formigas na interface solo-serapilheira a um gradiente de alteração ambiental. Iheringia, Série Zoologia, 103: 104-109. doi: 10.1590/S007347212013000200004.

Gotwald, W.H.Jr. (1995). Army ants: the biology of social predation. New York: Cornell University Press, 302p. doi: 10.1093/aesa/89.2.309

Groc, S., Delabie, J.H.C., Fernandez, F., Leponce, M.,Orivel, J., Silvestre, R.,Vasconcelos, H.L. \& Dejean, A. (2014). Leaf- 
litter ant communities (Hymenoptera: Formicidae) in a pristine Guianese rain-forest: stable functional structure versus high species turnover. Myrmecological News, 19: 43-51.

Hammer, O., Harper, D. A.T. \& Ryan, P.D. (2001). PAST: Paleontological Statistics Software Package for Education and Data Analysis. Ver. 2.04.<folk.uio.no/ohammer/past/>. Accessed date: December 9th. 2011.

Hölldobler, B. \& Wilson, E.O. (1990). The ants. Cambridge: Harvard University, 732 p. doi: 10.1046/j.1420-9101.1992. 5010169.x

Jimenez, E., Fernandez, F., Arias, T.M. \& Lozano-Zambrano, F.H. (2008). Sistemática, biogeografía y conservación de las hormigas cazadoras de Colombia. Colombia: Instituto de Investigación de Recursos Biológicos Alexander von Humboldt, $622 \mathrm{p}$.

Lach, L. (2005). Interference and exploitation competition of three nectar-thieving invasive species. Insectes Sociaux, 52: 257-262. doi: 10.1007/s00040-005-0807-z

Lattke, J.E. (2003). Subfamilia Ponerinae. In F. Fernandez (Ed.). Introduccíon a las hormigas de la región Neotropical (pp.261-281). Bogotá: Instituto de Investigación de Recursos Biológicos Alexander von Humboldt.

Leivas, F.W.T. \& Carneiro, E. (2012). Utilizando os hexápodes (Arthropoda, Hexapoda) como bioindicadores na biologia da conservação: avanços e perspectivas. Estudos de Biologia: Ambiente e Diversidade, 34: 203-213. doi: 10.7213/estud. biol.7333

Lyal, C.H.C. \& Weitzman, A.L. (2004). Taxonomy: exploring the impediment. Science, 305: 1106. doi: 10.1126/science. 305.5687.1106a

Macedo, L.P.M., Berti Filho, E. \& Delabie, J.H.C. (2011). Epigean ant communities in Atlantic Forest remnants of São Paulo: a comparative study using the guild concept. Revista Brasileira de Entomologia, 55: 75-78. doi: 10.1590/S008556262011000100012

Martins, L., Almeida, F.S., Mayhe-Nunes, A.J. \& Vargas, A.B. (2011). Efeito da complexidade estrutural do ambiente sobre as comunidades de formigas (Hymenoptera: Formicidae) no município de Resende, RJ, Brasil. Revista Brasileira de Biociências, 9: 174-179.

Medeiros, F.N.S. (1997). Ecologia comportamental da formiga Pachycondylastriata Fr. Smith (Formicidae: Ponerinae) em uma floresta do sudeste do Brasil. 1997. 70p. Dissertação (Mestrado em Ciências Biológicas). Universidade Estadual de Campinas, Campinas, SP.

MMA - Ministério do Meio Ambiente. (2006). Plano de manejo para uso múltiplo da Floresta Nacional TapirapéAquiri. Brasília:MMA/IBAMA, 453p.

Montine, P.S.M., Viana, N.F., Almeida, F.S., Dattilo, W.,
Santanna, A.S., Martins, L. \& Vargas, A.B. (2014). Seasonality ofepigaeic ant communities in a Brazilian Atlantic Rainforest. Sociobiology 61: 178-183. doi: 10.13102/sociobiology. v61i2.178-183

Neves, F.S., Braga, R.F., Espírito-Santo, M.M., Delabie, J.H.C., Fernandes, G.W. \& Sánchez-Azofeifa, G.A. (2010). Diversity of arboreal ants in a Brazilian tropical dry forest: effects of seasonality and successional stage. Sociobiology, 56: 1-18.

Passos, L. \& Oliveira, P.S. (2002). Ants affect the distribution and performance of Clusiacriuva seedlings, a primarily birddispersed rain forest tree. Journal of Ecology, 90: 517-528. doi: 10.1046/j.1365-2745.2002.00687.x

Passos, L. \& Oliveira, P.S. (2004).Interactions between ants and fruits of Guapiraopposita (Nyctaginaceae) in a Brazilian sand plain rain forest: ant effects on seeds and seedling. Oecologia, 139: 376-382. doi: 10.1007/s00442-004-1531-5

Peroni, N. \& Hernandez, M.I.M. (2011). Ecologia de populações e comunidades. Florianópolis: CCB/EAD/UFSC. 123p.

Rolim, S.G., Couto, H.T.Z., Jesus, R.M. \& França, J.T. (2006). Modelos volumétricos para a Floresta Nacional do Tapirapé-Aquirí, Serra dos Carajás (PA). Acta Amazonica, 36: 107-114. doi: 10.1590/S0044-59672006000100013

Schmidt, C.A. \& Shattuck, S.O. (2014). The higher classification of the ant subfamily Ponerinae (Hymenoptera: Formicidae), with a review of ponerine ecology and behavior. Zootaxa, 3817: 01-242. doi: 10.11646/zootaxa.3817.1.1

Schmitz, H.J., Amador, R.B., Ferreira, J.E.D., Maues, M.M., Nascimento, I.M. \& Martins, M.B. (2014). Relações biodiversidade vs. clima em escala local: um estudo de caso em busca de padrões espaço-temporais em insetos. In: T. Emilio \& F. Luizão (Orgs) Cenários para a Amazônia: clima, biodiversidade e uso da terra (pp. 19-30). Manaus: Editora INPA.

Silva, R.R. \& Brandão, C.R.F. (1999). Formigas (Hymenoptera: Formicidae) como indicadores da qualidade ambiental e da biodiversidade de outros invertebrados terrestres. Biotemas, 12: $55-73$.

Silva, R.R. \& Brandão, C.R.F.(2010). Morphological patterns and community organization in leaf-litter ant assemblages. Ecological Monographs, 80: 107-124. doi: 10.1890/08-1298.1

Silva, R.R. \& Silvestre, R.R. (2000). Diversidade de formigas (Hymenoptera: Formicidae) em Seara, Oeste de Santa Catarina. Biotemas, 13: 85-105.

Silva, E.M., Medina, A.M., Nascimento, I.C., Lopes, P.P., Carvalho, K.S. \& Santos, G.M.M. (2014). Does ant community richness and composition respond to phytophysiognomical complexity and seasonality in xeric environments? Sociobiology 61: 155-163.doi: 10.13102/sociobiology.v61i2.155-163

Silvestre, R.; Brandão, C.R. \& Silva, R.R. (2003). Grupos funcionales de hormigas: el caso de los grêmios del Cerrado. 
En:F. Fernández(Ed.). Introducción a las hormigas de la región Neotropical (pp.113-148). Bogotá: Instituto de Investigación de Recursos Biológicos Alexander von Humboldt.

Souza Filho, J.D.C., Ribeiro, A., Costa, M.H. \& Cohen, J.C.P. (2005). Mecanismos de controle da variação sazonal da transpiração de uma floresta tropical no nordeste da Amazônia. Acta Amazonica 35: 223-229. doi: 10.1590/S0044-59672 005000200012

Townsend, C.R., Begon, M. \& Harper, J.L. (2006). Fundamentos em Ecologia. Porto Alegre: Artmed, 592p.

Vargas, A.B. (2011). Diversidade de formigas em fragmentos florestais no vale do Paraíba, Vassouras, Rio de Janeiro. 2011. 79p. Tese (Doutorado em Ciências Ambientais e Florestais), Universidade Federal Rural do Rio de Janeiro, Seropédica, RJ.

Vargas, A.B.,Mayhé-Nunes, A.J., Queiroz, J.M., Souza, G.O. \& Ramos, E.F. (2007). Efeitos de fatores ambientais sobre a mirmecofauna em comunidade de restinga no Rio de Janeiro,
RJ. Neotropical Entomology, 36: 28-37. doi: 10.1590/S1519566X2007000100004

Vasconcelos, H.L., Macedo, A.C.C. \& Vilhena, J.M.S. (2003). Influence of topography on the distribution of ground-dwelling ants in an Amazonian Forest. Studies on Neotropical Fauna and Environment, 38: 115-124. doi: 10.1076/snfe.38.2.115.15923

Vogt, J.T., Smith, W.A., Grantham, R.A. \& Wright, R.E. (2003). Effects of temperature and season on foraging activity of red imported fire ants (Hymenoptera: Formicidae) in Oklahoma. Environmental Entomology, 32: 447-451. doi: 10.1603/0046225X-32.3.447

Wilkie, K.T.R., Mertl, A.L. \& Traniello, J.F.A. (2010). Species diversity and distribution patterns of the ants of Amazonian Ecuador. Plos One, 5: 1-12. doi: 10.1371/journal.pone.0013146

Wolda, H. (1988). Insect seasonality: why? Annual Review of Ecology and Systematics, 19: 1-18. doi: 10.1146/annurev. es.19.110188.000245

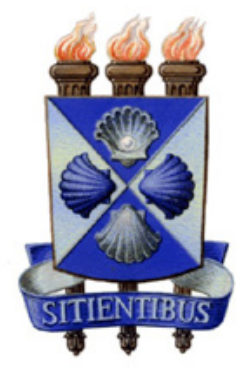

